American Journal of Applied Sciences 1 (2): 71-75, 2004

ISSN 1546-9239

(c) Science Publications, 2004

\title{
On the Optimum Numbers of Stages in Vapour Compression Refrigeration Systems
}

\author{
Durriye Bilge and Galip Temir \\ Mechanical Engineering Faculty, \\ Yildiz Technical University, 34349 Besiktas, Istanbul, Turkey
}

\begin{abstract}
In this study, cases of single-stage and multi-stage compression have been compared and contrasted through various angles while concentrating on refrigeration systems with $600 \mathrm{~kW}$ cooling capacity and working with ammonia. For five different numbers of stages, power consumption, costs of investment, operation and maintenance $(\mathrm{O}$ and $\mathrm{M}), \mathrm{COP}$ and 2 nd law efficiencies have been calculated. As the amount of stages increase, power consumption decreases. The payback period of the gain from this decrease has been calculated as far as the increasing investment expenditures are concerned. Dimensionless profit factor has been calculated according to each case and presented in the diagram.
\end{abstract}

Key words: Optimum numbers, vapour compression, refrigeration systems

\section{INTRODUCTION}

Increasing power consumption and the provision of power from significantly limited natural resources in the world, cause costs rise day by day. Environmental pollution caused by power consumption and competitive atmosphere which necessitates more productive/profitable use of financial resources, lead researchers concentrate their studies on this issue.

The most frequently used refrigeration cycle is the vapour-compression refrigeration cycle. The efficiency of a refrigerator is expressed in terms of the "Coefficient of Performance" (COP). COP is the ratio of the heat removed from the space to be refrigerated to the work to consume in order to accomplish this. As COP value rises, power consumption decreases ${ }^{[1]}$.

Chen et $a .^{[2]}$ used a model which included the irreversibility of heat transfer across finite temperature differences, the heat leak loss between the external heat reservoirs and the internal irreversibility of the working fluid to analyze the COP of a multi-stage combined refrigeration system. Roasts' and Brown ${ }^{[3]}$ also studied staged compression and focused on cascading an ideal vapor compression cycle and determined the optimal intermediate temperatures based on the entropy generation minimization method. Nikolaidis and Probert $^{[4]}$ and Yumrutas et al. $^{[5]}$ Analyzed refrigeration cycle basing their studies on the Second Law of Thermodynamics. Kaushik et al. ${ }^{[6]}$ Derived a general expression for the optimum COP of a refrigerator at minimum power input and given cooling load conditions. They studied the effect of various operating parameters on the cooling performance of the cascaded refrigeration cycles. Acadia and Rossi ${ }^{[7]}$ and Wall ${ }^{[8]}$ applied the exergoeconomic method blending 2nd Law and economic analysis for optimization of refrigeration systems.

An application: Schematic layout of the three-stage system which is used as the calculation model has been presented in Fig. 1. The cold room temperature is 270 $\mathrm{K}$. Cooling load (evaporator capacity) is $600 \mathrm{~kW}$. These values have been accepted constant for 5 different systems analyzed. Refrigerant is R717 (ammonia). Inlet-outlet temperature difference of cold room air in evaporator has been assumed as $5^{\circ} \mathrm{C}$. Heat loses and gains to the surroundings are negligible. Pressure drop of the refrigerant is $20 \mathrm{kPa}$ both in evaporator and evaporative condenser. Ambient temperature is $303 \mathrm{~K}$ (Istanbul, summer design temperature). Compressors' isentropic efficiencies have been assumed $80 \%$ and electric motors' efficiencies have been assumed $90 \%$. The condenser inlet pressure of ammonia is $1515 \mathrm{kpa}$ and evaporator inlet pressure is $210.1 \mathrm{kPa}$ constantly. The numbers of the stages increase from one to five in order to analyze the effect of staged compression on the costs of investments and $\mathrm{O}$ and $\mathrm{M}$. After each state a flash intercooler has been used in order to provide that ammonia flows into the next compressor as saturated vapor. Pressure drops in the pipe connections and flash intercoolers have been neglected. While interstage pressures are maintained, the optimum values, which will minimize isentropic compression work, have been calculated. For example, in the case of a two-stage refrigeration system, the optimal interstage pressure between the condenser and evaporator is $\mathrm{P}=\left(\mathrm{P}_{\mathrm{kon}} \times \mathrm{P}_{\mathrm{ev}}\right)^{1 / 2}$ and in a case of a three-stage refrigeration system with two intercoolers, intermediate pressures ( $\mathrm{PX}$ and $\mathrm{P}_{\mathrm{y}}$ ) in terms of inlet and outlet pressures $\left(\mathrm{P}_{1}\right.$ and $\left.\mathrm{P}_{2}\right)$ have been obtained as $\mathrm{P}_{\mathrm{x}}=\left(\mathrm{P}_{1}^{2} \cdot \mathrm{P}_{2}\right)^{1 / 3}, \mathrm{P}_{\mathrm{y}}=\left(\mathrm{P}_{1} \cdot \mathrm{P}_{2}\right)^{1 / 3}$. 


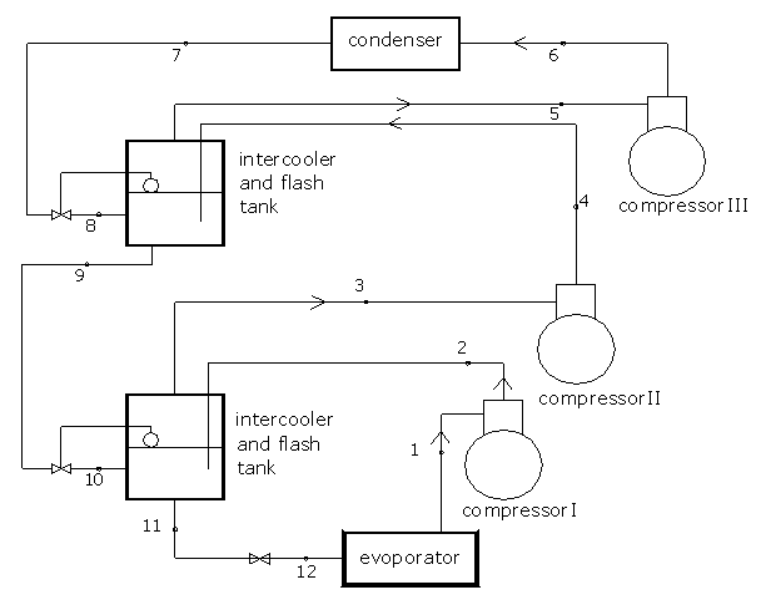

Fig. 1: Shematic of three-stage vapor compression refrigeration cycle studied

Thermodynamic calculations: The mass balance equation can be expressed in the root form as:

$\sum \dot{\mathrm{m}}_{\mathrm{i}}=\sum \dot{\mathrm{m}}_{\mathrm{e}}$

The general energy balance:

$\dot{\mathrm{Q}}+\sum \dot{\mathrm{m}}_{\mathrm{i}} \mathrm{h}_{\mathrm{i}}=\dot{\mathrm{W}}+\sum \dot{\mathrm{m}}_{\mathrm{e}} \mathrm{h}_{\mathrm{e}}$

Exergy rates:

$\mathrm{e}=\left(\mathrm{h}-\mathrm{h}_{0}\right)-\mathrm{T}_{0}\left(\mathrm{~S}-\mathrm{S}_{0}\right)$

The equations above have been used to calculate state point properties. These values have been recalculated for each case of compression (single-stage, two-stage, three-stage, four-stage and five-stage compression cases) and presented as a model for threestage compression system in Table 1.

Work consumption of the systems is the sum of the works of compressors they have. For example in the case of a three-stage system:

$\Sigma \mathrm{W}_{\mathrm{kom}}=\mathrm{W}_{\mathrm{kom}, \mathrm{I}}+\mathrm{W}_{\mathrm{kom}, \mathrm{II}}+\mathrm{W}_{\mathrm{kom}, \mathrm{III}}$

$\Sigma \mathrm{W}_{\text {kom }}=0.479(1549.3-1438)+0.553(1575.3-1459)$ $+0.659(1599.3-1478)=197.56 \mathrm{~kW}$

Coefficient of performance of three-stage system is:

$\mathrm{COP}=\frac{\mathrm{Q}_{\mathrm{ev}}}{\mathrm{W}_{\text {kom }}}=\frac{600}{197.56}=3.03$

The second law efficiency of a system is ${ }^{[9]}$ :

$\varepsilon=\frac{\text { proposed available energy }}{\text { consumed available energy }}$ $\varepsilon=\frac{\dot{\mathrm{m}}_{\mathrm{a}}\left(\mathrm{e}_{\mathrm{a}, \mathrm{i}}-\mathrm{e}_{\mathrm{a}, \mathrm{e}}\right)}{\sum \mathrm{W}}$

In the last equation above, $\dot{\mathrm{m}}_{\mathrm{a}}$, is mass flow rate of cool room air wandering in the evaporator. $\mathrm{e}_{\mathrm{a}, \mathrm{i}}$ and $\mathrm{e}_{\mathrm{a}, \mathrm{e}}$ are specific excercise in the inlet and outlet conditions of the air in and out of the evaporator and are calculated from Eq. 3. Compressor works, which have been calculated for five different refrigeration system analyst, COP and 2nd law efficiencies have been presented in Table 2 .

Economic calculations: Capacities of the components of the systems are known. Using these values, collecting the prices from the free market, Table 3 has been arranged for showing the costs of investment for the five different cases analyzed. While calculating the $\mathrm{O}$ and $\mathrm{M}$ expenditures, working hours of the systems per year have been assumed as $7300 \mathrm{~h} /$ year. Purchase of the electricity from network costs $0.07 \$ / \mathrm{kWh}$. Power consumption of the pump and fan in the evaporative condenser and again, power consumption of fans in the evaporator has been taken into account. As far as tax and insurance expenditures are concerned, $5 \%$ of total costs of investment has been maintained. $\mathrm{O}$ and $\mathrm{M}$ expenditures calculated for the five systems analyst has been presented in Table 4 .

Several methods can be used for economic analysis and calculation of payback periods ${ }^{[10-12]}$. In this survey, the simplest and most understable method is used. The payback period of a system can be calculated through the equation below ${ }^{[12]}$ :

$\mathrm{t}_{\mathrm{g}}=\frac{\ln \left[\frac{\mathrm{G}_{\mathrm{i}}}{\mathrm{G}_{\mathrm{i}}-\mathrm{G}_{\mathrm{y}} \mathrm{f}}\right]}{\ln (1+\mathrm{f})}$ [year]

Here, the interest rate is assumed constant as $\mathrm{f}=2 \%$. As will be seen in Table 3, as the numbers of the stages increase, the first costs of investment increase, too. However, $\mathrm{O}$ and $\mathrm{M}$ expenditures decrease while the numbers of the stages rise because the power used is reduced. In Equation 7, $\mathrm{G}_{\mathrm{y}}$ is the difference between the multi-stage compression and single-stage compression as far as the first costs of investment are concerned and as the number of stages increases, $G_{y}$ rises.

$\mathrm{G}_{\mathrm{i}}$ is amount of finance (in \$) saved with the decrease of $\mathrm{O}$ and $\mathrm{M}$ expenditures as far as the comparison between the multi-stage system and singlestage one is concerned. For example, the payback period for the three-stage system ( $\mathrm{tg}$ ) can be found out as below:

$\mathrm{t}_{\mathrm{g}}=\frac{\ln \left[\frac{26,396}{26,396-38,750 \times 0,02}\right]}{\ln (1,02)}=1.504$ year 
American J. Appl. Sci., 1 (2), 71-75, 2004

Table 1: State point properties in the three-stage refrigeration system

\begin{tabular}{lllllll}
\hline $\begin{array}{l}\text { State } \\
\text { point }\end{array}$ & $\begin{array}{l}\text { Temp. } \\
\left({ }^{\circ} \mathrm{C}\right)\end{array}$ & $\begin{array}{l}\text { Pressure } \\
(\mathrm{kPa})\end{array}$ & $\begin{array}{l}\text { Entholpy } \\
(\mathrm{kJ} / \mathrm{kg})\end{array}$ & $\begin{array}{l}\text { Entropy } \\
(\mathrm{kj} / \mathrm{kgK})\end{array}$ & $\begin{array}{l}\text { Mass flow } \\
\text { rate }(\mathrm{kg} / \mathrm{s})\end{array}$ & $\begin{array}{l}\text { Exergy } \\
(\mathrm{kJ} / \mathrm{kg})\end{array}$ \\
\hline 1 & -20 & 190.1 & 1438 & 5.904 & 0.479 & 34.91 \\
2 & 33.6 & 381.4 & 1549.3 & 5.977 & 0.479 & 123.872 \\
3 & -3.13 & 381.4 & 1459 & 5.662 & 0.553 & 129.962 \\
4 & 52.74 & 765.1 & 1575.3 & 5.735 & 0.553 & 223.924 \\
5 & 16.48 & 765.1 & 1478 & 5.417 & 0.659 & 323.932 \\
6 & 75.48 & 1555 & 1599.3 & 5.486 & 0.659 & 290.912 \\
7 & 39.52 & 1535 & 388.3 & 1.637 & 0.659 & 285.098 \\
8 & 16.48 & 765.1 & 388.3 & 1.656 & 0.659 & 291.402 \\
9 & 16.48 & 765.1 & 277.1 & 1.272 & 0.553 & 287.118 \\
10 & -3.13 & 381.4 & 277.1 & 1.286 & 0.553 & 299.320 \\
11 & -3.13 & 381.4 & 185.6 & 0.947 & 0.479 & 0.479 \\
12 & -17.72 & 210.1 & 185.6 & 0.956 & & 296.751 \\
\hline
\end{tabular}

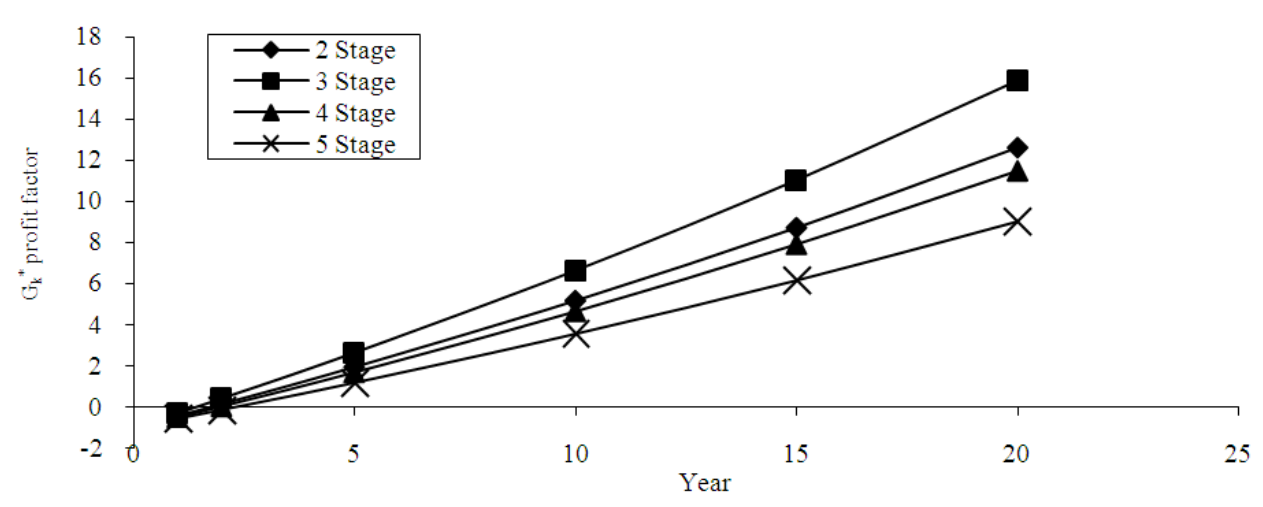

Fig. 2: Change of dimensionless profit factor $\left(\mathrm{G}_{\mathrm{k}}^{*}\right)$ in different operation periods

Table 2: Compressor works in the refrigeration systems, COP and 2nd Law efficiency values in different number of stages

\begin{tabular}{llll}
\hline Stage number & $\mathrm{W}(\mathrm{kW})$ & $\mathrm{COP}$ & $\varepsilon$ \\
\hline 1 & 227.66 & 2.64 & 0.347 \\
2 & 205.47 & 2.92 & 0.385 \\
3 & 197.56 & 3.03 & 0.4 \\
4 & 194.03 & 3.09 & 0.41 \\
5 & 189.81 & 3.16 & 0.417 \\
\hline
\end{tabular}

The profit that will be obtained during the operation period of different refrigeration systems has been calculated in the following equation ${ }^{[12]}$ :

$\mathrm{G}_{\mathrm{k}}=\mathrm{G}_{\mathrm{i}} \frac{(1+\mathrm{f})^{\mathrm{i}}-1}{\mathrm{f}}-(1-\mathrm{f})^{\mathrm{i}} \cdot \mathrm{G}_{\mathrm{y}}$

$\mathrm{i}=1 \ldots . \mathrm{n}$ years is the operational life of the system. The operational life of the five systems analyst in this study has been assumed 15 years. Dimensionless value profit factor is calculated as:

$$
\mathrm{G}_{\mathrm{k}}^{*}=\frac{\mathrm{G}_{\mathrm{k}}}{\mathrm{G}_{\mathrm{y}}}
$$

\section{RESULTS}

Payback periods of additional investment costs caused by multi-stage compression have been calculated 1.887 years for two-stage system, 1.504 years for a three-stage system and 2.059 years and 2.596 years for four-stage and five-stage years respectively. The systems' dimensionless profit factor values $\left(G_{k}^{*}\right)$, in other words, the ratio of the profit gained at different operation periods to the costs of investment, has been calculated with Equation 8 for 2, 5, 10, 15 and 20 years and shown in graphical form in Fig. 2.

As seen in profit factor data, the most economical system is the three-stage one. System amortizes itself in 1.504 years and starts to profit. If, for example, the system is utilized, 15 years a profit of 11.4 times the additional cost of investment is gained.

Technically speaking, as the number of the stages increases, condenser capacity becomes smaller and compressor outlet (condenser inlet) temperature becomes lower. When the compressor outlet temperature is $167^{\circ} \mathrm{C}$ in the single-stage system, it is $96^{\circ} \mathrm{C}$ in the two-stage system, $75^{\circ} \mathrm{C}$ in the three-stage system and $66^{\circ} \mathrm{C}$ and $60^{\circ} \mathrm{C}$ in the four and five-stage systems respectively. The decrease in the compressor outlet temperature causes a compressors' volumetric efficiencies increase ${ }^{[13]}$. Furthermore, properties of lubrication oil of compressors in high temperatures are known to be deteriorated. Besides, as the compressor pressure ratio increases, COP also falls (Table 2).

The increase in COP provided with stage compression, which provides a decrease in power consumption, will help reduce the environmental pollution caused by power production systems. 
American J. Appl. Sci., 1 (2), 71-75, 2004

Table 3: The costs of investment (US\$) in the studied refrigeration systems

\begin{tabular}{llllll}
\hline Unit & $\begin{array}{l}\text { Single-stage } \\
\text { Compression }\end{array}$ & $\begin{array}{l}\text { Two-stage } \\
\text { Compression }\end{array}$ & $\begin{array}{l}\text { Three-stage } \\
\text { Compression }\end{array}$ & $\begin{array}{l}\text { Four-stage } \\
\text { Compression }\end{array}$ & $\begin{array}{l}\text { Five-stage } \\
\text { Compression }\end{array}$ \\
\hline Compressor(s) & 25,250 & 32,050 & 37,400 & 41,900 & 45,920 \\
Condenser & 12,400 & 12,100 & 11,800 & 11,800 & 11,800 \\
Liquid tank & 3,000 & 3,000 & 3,000 & 3,000 & 3,000 \\
Expansion valve(s) & 9,500 & 16,000 & 19,000 & 24,000 & 30,000 \\
Main Power Panel & 14,500 & 14,500 & 15,000 & 15,000 & 16,000 \\
Electric cable installation & 6,800 & 7,000 & 7,000 & 7,000 & 7,400 \\
Ammonia & 3,000 & 3,000 & 3,000 & 3,000 & 3,000 \\
Flash tank(s) & - & 5,000 & 10,000 & 15,000 & 20,000 \\
Evaporator & 50,400 & 50,400 & 50,400 & 50,400 & 50,400 \\
Labour cast & 15,000 & 18,000 & 21,000 & 22,000 & 22,500 \\
Piping installation & 12,500 & 12,500 & 13,500 & 14,000 & 14,250 \\
Total investment $(\$)$ & 152,350 & 173,550 & 191,100 & 207,100 & 224,270 \\
\hline
\end{tabular}

Table 4: Annual operation and maintenance expenditures (US\$/year) of the studied refrigeration systems

\begin{tabular}{|c|c|c|c|c|c|}
\hline Unit & $\begin{array}{l}\text { Single-stage } \\
\text { Compression }\end{array}$ & $\begin{array}{l}\text { Two-stage } \\
\text { Compression }\end{array}$ & $\begin{array}{l}\text { Three-stage } \\
\text { Compression }\end{array}$ & $\begin{array}{l}\text { Four-stage } \\
\text { Compression }\end{array}$ & $\begin{array}{l}\text { Five-stage } \\
\text { Compression }\end{array}$ \\
\hline Compressor(s) electric power & 129,283 & 116,660 & 100,950 & 99,149 & 96,987 \\
\hline Evaporative conderser's and pump's and fan alike. & 30,660 & 30,660 & 30,660 & 30,660 & 30,660 \\
\hline Evaporator fan & 15,300 & 15,330 & 15,330 & 15,330 & 15,330 \\
\hline Servicing and spare parts costs & 21,900 & 21,900 & 21,900 & 21,900 & 21,900 \\
\hline Taxes and insurance costs & 7,618 & 8,678 & 9,555 & 10,355 & 11,214 \\
\hline Personnel costs (one person) & 6,000 & 6,000 & 6,000 & 6,000 & 6,000 \\
\hline Total operation and maintenance costs (US\$/year) & 210,791 & 199,228 & 184,395 & 183,394 & 182,091 \\
\hline
\end{tabular}

\section{Nomenclature:}

COP Coefficient of performance of refrigeration system

E specific exergy on a mass basis $[\mathrm{kj} / \mathrm{kg}]$

$\mathrm{F}$ interest rate [\%]

$\mathrm{G}_{\mathrm{i}}$ Annual net saving obtained through multi-stage compression [\$/year]

$\mathrm{G}_{\mathrm{k}}$ Profit obtained during the operation life of the system [\$]

$\mathrm{G}_{\mathrm{k}}^{*} \quad$ Dimensioenless profit factor

$\mathrm{G}_{\mathrm{y}}$ Annual net cost of additional investment caused by multi-stage compression [\$/year]

$\mathrm{H}$ specific enthalpy $[\mathrm{kj} / \mathrm{kg}]$

i $\quad \mathrm{i}=1 \ldots . \mathrm{n}$ years in operation life of the system

$\dot{\mathrm{m}}$ mass flow rate $[\mathrm{kg} / \mathrm{s}]$

$\mathrm{P}$ pressure $[\mathrm{kPa}]$

Q rate of heat transfer $[\mathrm{kW}]$

s specific entropy $[\mathrm{kj} / \mathrm{kgK}]$

$\mathrm{T}$ temperature $\left[{ }^{\circ} \mathrm{C}, \mathrm{K}\right]$

$\operatorname{tg}$ payback period of the system [year]

$\dot{\mathrm{W}}$ rate of work-power -of compressor [kW]

$\varepsilon \quad$ Second law efficiency [\%]

\section{Subscripts:}

A air i inlet

e outlet

ev evaporator

komcompressor

kon condenser

o dead state $\left(33^{\circ} \mathrm{C}\right.$ temperature and 1 bar pressure)

\section{REFERENCES}

1. Cengel, Y.A. and M.A. Boles, 1998. Thermodynamics An Engineering Approach. McGraw-Hill, Inc. New York.

2. Chen, J., X. Chen and W. Chik, 2002. Ecological optimization of a multi-stage irreversible combined refrigeration system. Energy Conversion and Management, 43: 2379-2393.

3. Ratts, E.B. and J.S. Brown, 2000. A generalized analysis for cascading single fluid vapour compression refrigeration cycles using an entropy generation minimalization method. Intl. J. Refrigeration, 23: 353-365.

4. Nikolaidis, C. and D. Probert, 1998. Exergymethod analysis of a two-stage vapourcompression refrigeration-plants performance. Appl. Energy, 60: 241-256.

5. Yumrutas, R., M. Kunduz and M. Kanoglu, 2002. Exergy analysis of vapor compression refrigeration systems. Exergy, 2: 266-272. 
6. Kaushik, S.C., P. Kumar and S. Jain, 2002. Performance evaluation of irreversible cascaded refrigeration and heat pump cycles. Energy Conversion and Management, 43: 2405-2424.

7. Accadia, M.D., 1998. Thermoeconomic optimization of a refrigeration plant. Intl. J. Refrigeration, 21: 42-54.

8. Wall, G., 1991. On the optimization of refrigeration machinery. Intl. J. Refrigeration, 14: 336-340.

9. Ertas, K., 2002. Available energy analysis of refrigeration systems. Msc. Thesis, Yildiz Technical University, Istanbul.
10. Heteu, P.M.T. and L. Bolle, 2002. Economie d'energie en Trigeneration. Intl. J. Therm. Sci., 41: 1151-1159.

11. ASHRAE Handbook-Applications, 1993, 33.0133.08.

12. Yilmaz, T., 1997. Heat recovery systems. Turkish 3rd HVAC and Sanitary Engineering Congr., pp: 109-133, Izmir.

13. Aprea, C., R. Mastrullo, C. Renno and G.P. Vonoli, 2003. An evolution of R22 substitute performance regulating continuously the compressor refrigeration capacity. Appl. Therm. Engg., 24: 127-139. 